\title{
INFORMED\& EDUCATED
}

\section{WHEN PUBLIC SERVICE RADIOLEARNS FROM THE COMMERCIAL RADIO SECTOR}

\author{
Daithí McMahon \\ University of Derby \\ School of Arts \\ College of Arts, Humanities and Education \\ Markeaton Street \\ Derby, DE22 3AW \\ United Kingdom \\ d.mcmahon@derby.ac.uk
}

\begin{abstract}
Using the Irish Radio Industry as a case study, this chapter illustrates how the public service broadcaster (PSB), Raidió Teilifís Éireann (RTÉ), was slow to react to change and the effect this had on the organisation's competitiveness. The chapter analyses how RTÉ's youth radio station, RTÉ 2fm, lost its place as the market leader to the competing commercial stations as it resisted the required technological, cultural and talent changes required which ultimately affected its listenership. The author argues that the independent radio sector led the way in innovation and affected change which greatly benefited the industry as a whole and brought public radio in Ireland into the digital age. The article outlines how commercial radio played a crucial role in the transition of radio into the digital age and how RTÉ enacted the required change to bring it in line with modern practice. This research was based on a methodology involving in-depth interviews, textual analysis, direct observation and a longitudinal content analysis.
\end{abstract}

Keywords: Facebook, Irish radio, social media, millennial audience, commercial radio, public service radio

\section{Introduction}

Although the medium of radio has fundamentally changed very little as an aural broadcast medium during its near century of existence, how producers and audiences interact evolved markedly and swiftly between the years 2008 and 2016. During this time the old, and in Ireland's case still predominantly analogue, medium of radio converged with digital media - most notably social network sites (SNSs). This transformation was driven by a number of factors including the increase in audience agency and capability, the growth of media convergence and micro and macroeconomic pressures. However, not all radio stations across the three sectors in Ireland were as responsive to change. In fact the commercial radio sector in Ireland was far more flexible, dynamic and innovative than its public service counterparts in RTÉ, and led the way towards progressive transformation. This alteration to radio production was 
forced by a steady shift in young listeners from RTÉ's national youth radio station $2 \mathrm{fm}$, to the four commercial regional youth stations between 2008 and 2014 (see graph below). When RTÉ did make the necessary modifications it did so swiftly, comprehensively and successfully - and rebranded RTÉ $2 \mathrm{fm}$ in the process.

Audience participation has long been a vital part of radio production as producers aim to engage the audience and seek responses via letters, phone, text, email or instant message. However, the nature of this participation changed as the contemporary audience all of a sudden had many more communication channels, due to the widespread availability of Facebook and other SNSs to radio stations and their audiences. A radio station's Facebook page is an extension of its enterprise, offering a more dynamic 'homepage' than its own website. Therefore stations post content complementing and promoting their on-air product - material which attracts and engages the audience and aims to secure their return in the future.

This article argues that radio's relevance as a medium in a modern, highly-competitive digital mediascape was safeguarded by the commercial radio sector - a band of thirty-four privately owned and operated radio stations represented by the Independent Broadcasters of Ireland (IBI). Leading stations from this sector, youth stations in particular, showed leadership, innovation and cunning at a time of peril for the industry, as the threat of digital audiovisual media increased. The commercial sector showed RTÉ in the public service sector how modern radio ought to be produced and how to adopt ancillary extensions such as SNSs to remain relevant to the modern audience. This isn't to say that the commercial sector always leads the way for the public service radio to follow but this study serves as an example when this was the case. This article also makes a valuable contribution to the area of radio production specifically in terms of the changes in production practices brought on as a result of the introduction of social media into the role of the producer. This has not only meant the expansion of the producer's remit to include SNS management, but also the introduction of new technologies into the studio and, in some instances, the recognised need for bespoke social and digital media editors/managers.

The observed period was a time not only of economic uncertainty in Ireland, but of technological and cultural change globally, as audiences became more active and digitally connected. This case study not only illustrates how resourceful and responsive radio stations can be, but on a larger scale also serves to reinforce the core qualities of radio as a highly resilient, flexible and adaptable medium that can survive adversity. Having endured the arrival of television in the 1950s and the threat posed by the Internet at the turn of the century, radio once again was able to prove its value and place in people's lives in the modern digital age - where multimedia content is ubiquitous. Radio has showed how an aural medium can compete at a time when portable devices, carrying primarily visual media, demand so much of our attention. The radio listeners of tomorrow, often referred to as 'digital natives', are growing up with multiple screens at their disposal. ${ }^{12}$ However, the question of whether users are being exploited by the tech giants for their time and data through the guise of 'play labour' is a very real concern that must be considered. ${ }^{3}$

\section{Background \& Context}

The Irish people are avid radio listeners with $82 \%$ of all adults listening to the radio each weekday, ${ }^{4}$ and although this is indeed a strong figure, it represents a drop from $86 \%$ in $2011 .{ }^{5}$ Among younger listeners aged $15-34,77 \%$ listen each weekday - somewhat below the average but still representing three in four young people. Irish radio audiences also listen for significant periods of time each day - on average four hours per weekday during the primetime hours of $7 \mathrm{am}$ to $7 \mathrm{pm}$. There exists healthy competition for listeners' ears between the national and local/regional stations as $57 \%$ of listeners tune in to their local or regional radio station, while $44 \%$ tune in to national stations, which include public service stations, each day. ${ }^{6}$

The Irish radio industry is broadly comprised of three sectors which are regulated by the Broadcasting Authority of Ireland (BAI) - the public service sector, the independent commercial sector and the community sector. Raidió Teilifís Éireann (RTÉ) is Ireland's public service broadcaster (PSB). It is a semi-state company which operates radio, 
television and online services nationally. The radio branch is comprised of four national stations, RTÉ Radio 1, RTÉ $2 \mathrm{fm}$, RTÉ Lyric fm and RTÉ Raidió na Gaeltachta, as well as eight digital-only services. RTÉ Radio 1 is a full-service station aimed at the 35-years-plus market segment; RTÉ $2 \mathrm{fm}$, which was involved in this study, is a music and entertainment station aimed at the 20 to 44 year old audience; RTÉ Lyric fm offers a classical music and arts format to an adult audience; and Raidió na Gaeltachta offers a full-service format exclusively through the Irish language to all ages. RTÉ's radio stations are managed centrally and funded via two revenue streams $-93 \%$ of the TV Licence fee and, unusually for a PSB, commercial advertising and sponsorship revenue. This double income set-up allows RTÉ to compete for commercial revenue with the commercial broadcasters, while also enjoying the safety net provided by the licence fee. This, one could argue, offers RTÉ a competitive advantage over their commercial rivals as it offers the PSB enviable resources. Due to RTÉ's large audiences, it is often able to under-cut the commercial competition, thus offering a strong competitive edge when competing for advertisers. RTÉ Radio 1 is the leading radio station in Ireland, and dominates the radio market in terms of listenership with 9 of the top 10 most-listened to radio programmes nationally. ${ }^{7}$ This is in itself a sign of RTÉ's strength and position in the industry. RTÉ staff levels are much higher compared to the private sector at a ratio of 3:1 based on the present research, and its staff are, on average, paid more than their commercial counterparts.

There are thirty-four independent commercial radio stations in Ireland, which include: two national, one multi-city, four regional and twenty-seven local stations serving the length and breadth of the country. All stations in the commercial sector are privately-owned and operated enterprises, receiving no financial support from the government or any direct share of the television licence fee. Despite having significantly less funds compared to RTÉ, the greatest asset local independent radio stations possess is the trust of, and unparalleled intimate connection with, their audience. Rather than being considered completely separate to public service radio it ought to be considered as forming part of it. Independent radio stations are obliged by their broadcast licences to offer public service content is the form of daily news and current affairs output while upholding the core values of public service media. The local news coverage proves a strong attraction for listeners of each county across the country. Reuters found radio to be the most trusted source of news and information for listeners in Ireland, ahead of TV and print media. ${ }^{8}$ Ireland's commercial radio sector was borne out of a need for plurality and competition in the Irish radio industry and many of the current stations started life as unlicensed commercial radio stations, otherwise known as pirate radio stations. ${ }^{9}$

There are distinct differences between the PSB and independent commercial sectors in Ireland which makes each unique and an integral part of a vibrant radio industry. However, despite the differences between the two they do have a shared public service remit and also compete for the same audiences. The competition for the youth audience is particularly prevalent between the public and commercial sectors in Ireland, but also in other countries such as Finland, Sweden and Germany..$^{10}$ This brings the competition between RTÉ $2 \mathrm{fm}$ and the youth stations for audiences into sharp focus. This is the battleground for the next generation of radio listeners.

The third part of the Irish radio industry is the community radio sector, which consists of twenty-one full-time and part-time radio stations operating as not-for-profit enterprises, owned and staffed by the members of the community which they serve. Despite the value and important position within the Irish Radio Industry that the community radio sector holds, it was not included in this study.

\section{Changing Mediascape}

The Irish Radio Industry found itself in a difficult position when the global economic recession hit in 2008, however, this was not the only force that was affecting change. There were also socio-technological forces to consider as people were using technology to connect with one another in ways not previously possible. Along with the sharp decline in advertising revenue the mass media were becoming increasingly globalised and digitalised and, more importantly for a medium that relies on audience participation, the audience was now afforded more control. 
With the emergence of convergence culture, where media and audiences were now merging and connecting in new and exciting ways, the audience had a new-found ability to influence matters. ${ }^{11}$ The audience now had the technological means and appetite to be involved in media production and connect with other listeners without the need for an intermediary, which was the role radio had previously played.

Discussion of the active audience stems from cultural studies theory which challenged media affect theory arguing that the audience are more active and in more control of the media messages they receive. This has progressed to the point where, in the current research, the audience is now a media producer as well as a consumer, with access to the means of production and distribution. This has altered the nomenclature to apply terms such as 'prosumer'12 and 'produser'13 as a reflection of the duel nature of the role now occupied by "the people formerly known as the audience". ${ }^{14}$ One could also refer to the audience as followers, users and viewers given the expansion of radio's multimedia output. Bardoel and Lowe proposed the relabelling of public service broadcasting to public service media (PSM) arguing the latter more accurately reflects the modern public service entities. ${ }^{15}$

Another aspect of convergence culture is that information flows were disrupted and not only reversed from the traditional top-down from media outlet to audience member, to bottom-up from audience to media producer, but the information flows could now also move horizontally between audience members, cutting out media outlets altogether. ${ }^{16}$ Social Network Sites (SNSs) have given the audience member the ability to engage with the mass media and with other users and use the platforms as sources of entertainment, information and communal engagement.

Along with this shift in power was the technological change in the form of media digitalisation and with it the need to make media more visual to engage a modern audience. These changes created both opportunities and threats for radio. Technological change had to be embraced but this influx of new technology into our lives has not been without its challenges. As users have become more digitally engaged they have been unwittingly giving their time and data to the SNS giants without any form of compensation. They are effectively being used and exploited in a modern form of slavery that Fuchs labels 'play labour' due to the enjoyment the users receive from their work on Facebook, Instagram and other SNSs. ${ }^{17}$ By engaging with radio stations on Facebook audiences are earning money for the tech giant revenue that could be going to supporting struggling commercial stations.

This article also focuses on the millennial audience which is the target audience of the two main radio stations in this study. Millennials - the generation born between roughly 1982 and the turn of the millennium - have had the unique experience of growing up with digital media as an ever-present part of their daily lives. ${ }^{18}$ Strauss \& Howe described the generation, who are predominantly the children of Baby Boomers, as being upbeat and engaged individuals markedly different from the generation before them. Sometimes referred to as 'digital natives', one would expect millennials to be difficult to attract to radio - given its main attribute as an aural medium. ${ }^{19}$ However, with the right content, delivered via the right channels at the right times, radio stations can overcome these challenges and reach young audiences to attain and maintain their attention and build loyalty over time.

Public service broadcasting has undergone a number of changes and developments in the near century since the establishment of the BBC in 1922 by John Reith ${ }^{20}$ yet its original model continues to be the dominant framework in Europe ${ }^{21}$ including Ireland, though with some variation. The PSB model is built on a collection of core values that are to serve the entire public and provide programming that informs, educates and entertains. PSBs ought to be independent from state and commercial interests, though in Ireland's case RTÉ has strong commercial interests. Public service broadcasting must also cultivate democracy while also promoting domestic culture. ${ }^{22}$ Commercial radio stations meanwhile are predominantly capitalist enterprises and thus profit oriented first and foremost. Their aim is to deliver the largest return to the shareholder which means maximising income while minimising costs. This leads many commercial stations to choose output which is cheap to produce but has the widest appeal such as music and/or entertainment formats with scant regard for public service content or informative programming of any kind. The Irish Radio Industry is an exception to this given the aforementioned commercial sector's public service obligations. 
Comparisons between the commercial and public service radio sectors in Ireland have not received adequate scholarly attention. In fact, literature on the Irish radio industry is sparse and that which is published largely focuses on RTÉ. ${ }^{23}$ This makes research, such as the present one, highly valuable as it forges a path for future researchers to follow and further explore the industry's past, present and future.

Mulryan charted the history of community and pirate radio in Ireland up to the introduction of legislation allowing licenced commercial radio stations to be established, something that was driven by the need to cater for the youth audience. ${ }^{24}$ Focusing on Scandinavian broadcasters Lowe and Maijanen offer an analysis of strategic management of digital media by public service broadcasters in northern Europe. ${ }^{25}$ The authors found the PSB entities to be slow to react to digital change to attract young audiences which was attributed to the challenge of maintaining the public service mission. This author has found a similar situation in Ireland - radio station management need to appeal to the younger audience members and know that digital media is the way to achieve this. Kemppainen wrote about the major radio programming changes that were implemented from the early 1990s by the respective PSBs in the Nordic countries - Sweden, Norway and Finland. ${ }^{26}$ The changes were introduced in order to attract younger listeners who were being drawn to the newly established commercial radio stations in the wake of deregulation which broke up the pirate stations. In the UK the BBC has had its own pressures applied by the commercial radio sector which led to the BBC's 'Extending Choice' plan which recommended BBC radio adapt and transform as commercial radio grew and developed. ${ }^{27}$ The idea was for the BBC to fulfil its public service remit and extend its offering significantly in the wake of competition to a wide range of programming that the commercial sector would not be in a position to cover.

\section{Methodology}

Two radio stations took full part in the study - an independent commercial station Beat 102103 (Beat) and one public service station RTÉ $2 \mathrm{fm}$ as the stations are in direct competition with one another. A senior manager was also interviewed at Spin South West, another regional youth station. Beat is a regional music and entertainment station for the 15-34-year-old market, covering a number of counties in the southeast region of Ireland. RTÉ $2 \mathrm{fm}$ is a music and entertainment station targeting 20-44 year olds and is the dedicated youth public service station and is therefore in competition with Beat and the other youth stations for young listeners/followers/users. Spin South West is similar to Beat as a regional station for the 15-34 year old market in the southwest of Ireland. The author does appreciate that there is an age discrepancy with regards the targeted audiences of the stations involved in this research, however RTÉ $2 \mathrm{fm}$ is the youth focused public service station and thus competing with the other youth stations. It has an unusual target audience especially when one considers the young audience bracket is 15-34 years. The author argues that RTÉ's targeting is too high and should be revised down by at least five years to 15 years at the lower end to match their competition and compete directly with their rivals. By twenty years of age most listeners have established their loyalty and it is thus far too late to attract them as new listeners.

The present research project involved several research methods: in-depth interviews, textual analysis, direct observation and content analysis with the former providing the bulk of the data. Six interviews were conducted with staff across the aforementioned radio stations. In order to monitor the posts, audience response, activity, and development of the radio station Facebook pages RTÉ $2 \mathrm{fm}$ and Beat, textual analysis of these pages was conducted over a five-year period 2011-2016. Direct observation of radio producers in the stations involved was conducted to record their production practices and content analysis was conducted of radio station Facebook pages to record follower figures over a three-year period (2011-2014). Close examination of the listenership figures offered by the Joint National Listenership Research (JNLR) was also involved. By employing multiple methods, the researcher was able to use a research method known as 'triangulation' to test the veracity of the findings and cancel any bias from one method ${ }^{28}$. The above research approaches the research problem from the perspective of the audience, the producer, and the text to consider all aspects of the research question. 


\section{Contrasting Approaches to SNS Management}

There was a distinct discrepancy found between the social media management and strategies of the independent commercial broadcasters studied compared to RTÉ $2 \mathrm{fm}$. The Facebook page content of the commercial stations was also found to be much more dynamic and effective at engaging and growing the online audience. The author proposes a correlation between the lack of digital engagement and the stations' listenership figures - the lifeblood of a radio station and the accepted measure of success or failure in radio.

Based on the findings the following themes were developed for the functions Facebook and other SNSs hold for commercial radio station management: Increase Online Presence, Station Promotion, Increase Participation, Interaction and Engagement \& Increase Listenership. The themes have been arranged into a logical flow to represent the strategy in action. Radio stations use SNSs to increase the station's online presence in the first instance so that station can promote itself and its output to encourage the target audience to increase their participation, interaction and engagement in the hope they will return as online visitors and, more importantly, on-air listeners which will increase listenership and thus revenue. RTÉ staff were more directly focused on using social media to support on-air programming and promoting the programme/station but maintaining the focus on the core product of producing quality radio content.

\subsection{Increased Online Presence}

The commercial radio station, Beat, was found to be very aggressive and innovative with social media and employed strategies that were geared to engage their target audience. Interviewees identified the need to have a strong online presence. The senior manager at Beat stressed their need to be prevalent online,

We need to be where the audience is [SNS sites] and to have a strong online presence on numerous platforms...we need to be online because that's what they're [the audience] at...so we have to make sure it's part of what we do.

The senior manager interviewed at Spin South West had a similar view point,

...people are increasingly using social media to communicate and we find that our target demographic of 15-34 year olds is spending at least an hour a day online including on social media. So we had to be where our audience is. Same reason we have promotional vehicles on the streets and at events because that's where our people are.

A member of the $2 \mathrm{fm}$ production team also noted being online as important, "We're on in the morning when most people are at work and they might not be able to listen to the radio but they can follow online so it's essential for us to have a presence online for people to see what's going on in the show". The $2 \mathrm{fm}$ presenter interviewed said they were online mainly because the competition were and therefore they didn't want to seem "old fashioned". There was general agreement across all interviewees that Facebook is very effective at offering a more attractive, dynamic and engaging online presence for the radio station that is complementary to the website but much more useful for promoting programmes and the station.

\subsection{Station Promotion}

The radio professionals interviewed agreed that the most useful function of Facebook for their radio station was as a marketing tool to promote the station. The Spin South West senior manager said, "It is an on-line marketing tool for 
our station, it's a way to connect with our audience... to drive people back to the website". A junior member of the 2 fm production team found it useful to promote the programme and what the team do in a visual way to which the $2 \mathrm{fm}$ producer added, "It's a good marketing tool...and it reinforces our presence and places us in that area. I think that Facebook is a good way of marketing the on-air talent". The Beat manager agreed, "It's social interaction, it is awareness of the station... Facebook is an extension of the brand".

\subsection{Increase Participation, Interaction and Engagement}

Once audience members arrive at a radio station Facebook page it is then the challenge of the production staff to make sure the user has a worthwhile experience so that they may return again in the future. Any form of interaction and engagement helps achieve this. Successful posts were those that 'went viral' and reached new audience members not already Facebook followers or on-air listeners. As a result Beat was successful and achieved online interaction and engagement as well as strong growth in Facebook followers during the period of study, building a following of over $108 \mathrm{k}$ in 2014 . The Beat senior manager adamantly contended that owing to the station's young audience being so connected to social media, that Beat would lose at least some of its audience to the competition, or miss out on attracting new youth listeners, if the station made less of an effort promoting the Beat brand via social media. The Beat senior manager said, "I'm constantly saying we should advertise radio on social media... radio listening will continue to decrease if we don't embrace social media".

\subsection{Increase Listenership}

The Beat manager claims that listenership increases are partly made up of new young radio audiences reached initially through Facebook and other SNSs. In other words, new radio audience members are being recruited online rather than on-air. Some of these come to the station earlier than 15 years old through SNSs. This was a point that $2 \mathrm{fm}$ staff did not appreciate - that young people are in the habit of engaging with SNSs before they develop radio listening habits. The $2 \mathrm{fm}$ junior staff member interviewed was working on a daily programme and described the programme format and target audience which highlight the difference between the target audience of the station involved in this study, "Our target listener is a woman in her late 20s early 30s, they are the ones who respond to our content on the show, so that's who we tailor to".

Conversely management in commercial youth stations target new audiences at ever younger ages to replenish the older ones who move on as their tastes mature. Managers and producers know that they must also attract those new listeners online to secure them as loyal SNS followers and on-air listeners. When asked what age they target on Facebook the Beat senior manager stated, "Definitely the 15 to 17 -year-old bracket, l'd even say starting at 12 or 13". This is an area in which commercial stations are demonstrating a competitive edge which is based on a strong understanding of youth media users' habits and preferences.

The Beat senior manager thought strongly that SNS could impact listenership,

...we've had consistent growth [in listenership], we probably could have gotten stagnant if we hadn't [embraced SNSs]... technologies are constantly evolving and I think some radio stations will fall back off the wheel if they don't go with them and embrace them [digital media]... since 2004 our weekly reach has grown consistently. I attribute that to constantly listening to what our audience wants.

The same interviewee explained how they need to target future listeners, "the audience at night time is very much the teenagers and if we don't have them we're not going to have an audience in the future...[the presenter] has to 
absolutely drive the online side of it, interacting online with audiences via Instagram, Twitter etc". The Beat presenter interviewed explained how using social media as part of a strategy can help increase their listenership,

....if we can get something into their feed on Twitter or Facebook.... to recall your station name when it comes to JNLR time....that's where I think social media really comes into it. Good on-air product is very important obviously, but being seen is crucial to ratings because you stick out in people's minds when they are answering the JNLR survey. We can't afford the same advertising as our competitors RTÉ 2fm and Today FM. We've noticed positive figures in the JNLRs from being visible.

The Spin South West senior manager interviewed believes their station is gaining listeners for a number of reasons but is not convinced it's primarily down to social media,

All of the young stations are gaining listeners as the market becomes more fractured and we're capturing the new listeners until they reach 30 or so and move on. We offer them more music and less talk, which appeals to younger people.

The RTÉ $2 \mathrm{fm}$ producer interviewed disagreed that Facebook could be linked to listenership,

No, I don't think Facebook helps us get any more listeners...I have yet to see the figures that would support that, but...I don't think it connects people in that way, not yet anyway.

The $2 \mathrm{fm}$ presenter interviewed concurred,

No is the simple answer. I think it's a nice toy for those who listen, I don't think it's actually going to garner more listeners. The only way we're going to get more listeners is by having a good radio show, not a Facebook page.

As the graph in Figure 1 below shows listenership increased over the period of study for each youth commercial station, pointing to a positive response from the target audience and a gravitation of young listeners to the stations and their output. Enli \& Ihlebaek found that facilitating audience interaction through social media by the mass media can help build audience loyalty. ${ }^{29}$ Managers and producers at the commercial radio stations involved in this study stated their motivation behind using Facebook was to engage audiences in the expectation that they will return as radio listeners - thus increasing revenue. The Beat senior manager stated,

I think if we weren't talking with them on Facebook we wouldn't have them on-air...because it is such a big part of their life at the moment. We have to be able to encourage them to come back to us on-air. Our primary goal is to grow our audience on-air and Facebook helps us do that. I'm killing the guys if they're not [using social media], if we're doing something on-air we have to be supplementing it online.

Hence, building audience loyalty is the primary motive and replicates their on-air strategy which aims to keep the listener tuned in. Analysis of the radio station Facebook pages shows that audiences want to interact with other users and participate in online discussions and Facebook offers them these opportunities.

The research found that the commercial station staff were more premeditated in their approach to attracting and engaging listeners. A lot of thought and consideration went into the posts, predominantly self-curated memes, that aimed to tap into the zeitgeist of the audience. As the Beat senior manager stated, having a strategy is important,

....you have to have a strategy with your Facebook page, you can't just have all these 'Likes' and do nothing with them, you have to engage with the people, you have to make sure it's active and it's a live page and community driven and I think we do that really well by whatever we're doing on-air we're doing on Facebook. 
The Spin South West manager took the next step and hired a dedicated digital media editor with particular expertise in the area which shows the level of strategic foresight at the station,

We have a social media editor...she knows all about SEOs and plug-ins etc. She is dedicated to social media and online content... if you have somebody who can reach 32,000 people with a post wouldn't you be mad not to have someone working on that full-time?

Conversely $2 \mathrm{fm}$ staff were content to let the star power of their popular presenters attract and engage the SNS audience and let their numerous staff share in the social media management duties despite their lack of expertise. This may have proven effective at engaging existing followers, and there is evidence in the comments from the Facebook page that supports this. However, the same posts were not highly effective in expanding the online audience by attracting new followers as was the case with the competition. Beat staff were able to turn existing followers into ambassadors of the station who shared memes with those in their social circles. There were noticeable increases in Beat Facebook followers after the posting of popular memes and other material that connected emotionally with users. Successful posts were the ones that used nostalgia to bring back memories of their past while also making the audience member feel as if they were part of a wider community of users with similar life experiences. Mannheim argues that shared experiences from our past brings the participants closer together thus shared childhood memories can have the effect of drawing people of the same age group closer to the station and its followers. ${ }^{30}$

RTÉ 2fm's production staff, although accepting the need for SNS presence, were less enthused about the need to have a high level SNS activity or to give too much credence to the power of SNSs. The researcher, and youngest member of the team, was the most committed and active SNS user and predominantly posted filtered photos of the programme's host on Facebook and Instagram. These posts garnered on average 100-300 reactions from the $21 \mathrm{k}$-plus followers in 2014, however the strategy was limited in its dynamism as it merely offered a window into life behind the scenes of the radio show. The posts offered the audience what it craved most of all, according to the show's researcher, a focus on the star of the show. Despite the lack of emphasis on social media, the presenter and producer interviewed were quick to stress the importance of the show's core product - "quality on-air programming". The $2 \mathrm{fm}$ producer stated, "Certainly on the face of it, it's [Facebook] a very popular user friendly meeting place where our show can meet with our listeners. Our main aim is on-air content and info that goes out on-air".

It must be noted that every radio professional offered this same response at some point during interview - the on-air product is the most important. Despite this valid argument, the author argues that both quality on-air programming and dynamic and innovative social media management are essential aspects of modern radio production and that both can be effectively achieved. Furthermore, the author posits that both must be achieved by radio stations in order to be successful in the modern digital era.

Much of RTÉ's reluctance to adopt new technology possibly stems from a historical culture of conservative programming that aims to maintain traditional values and thus please the older audience member. As Browne writes, “...RTÉ has represented a conservative cultural institution, careful about its responses to change and challenges". ${ }^{31}$ Lowe and Maijanen found similar difficulties with Scandinavian PSBs. ${ }^{32}$ Change was stymied in many cases by the difficulty not of technological change but of cultural change in Nordic PSBs. This is seen again in the present study which found a staunch reluctance to move with the times and accept the inevitable need to evolve. The author's findings during the period of research revealed the programming and digital output of $2 \mathrm{fm}$ to be prosaic and very safe in comparison to Beat and other commercial stations.

RTÉ has long struggled with the challenges and competition posed by youth radio and the present study is not the first time RTÉ was forced to make alterations to its offering. In 1979 Radio 2, as RTÉ 2fm was known then, was first launched in response, and as direct competition to, the illegal pirate radio stations which enjoyed large listenership and strong profits ${ }^{33}$. The pirates proved that the demand existed for wall-to-wall top 40 music programming which, at the time, was not provided by RTÉ. The new youth station was rebranded as $2 \mathrm{fm}$ in 1989 to compete with the newly-licenced, former pirate, commercial radio stations. From 2008 RTÉ 2fm was again upstaged by the arrival of 
the new youth radio stations Spin South West and the iRadio twin stations and eventually had to accept that change was inevitable if it was to compete for the attentions of the modern media consumer/user, where media is increasingly digital, social, and visual.

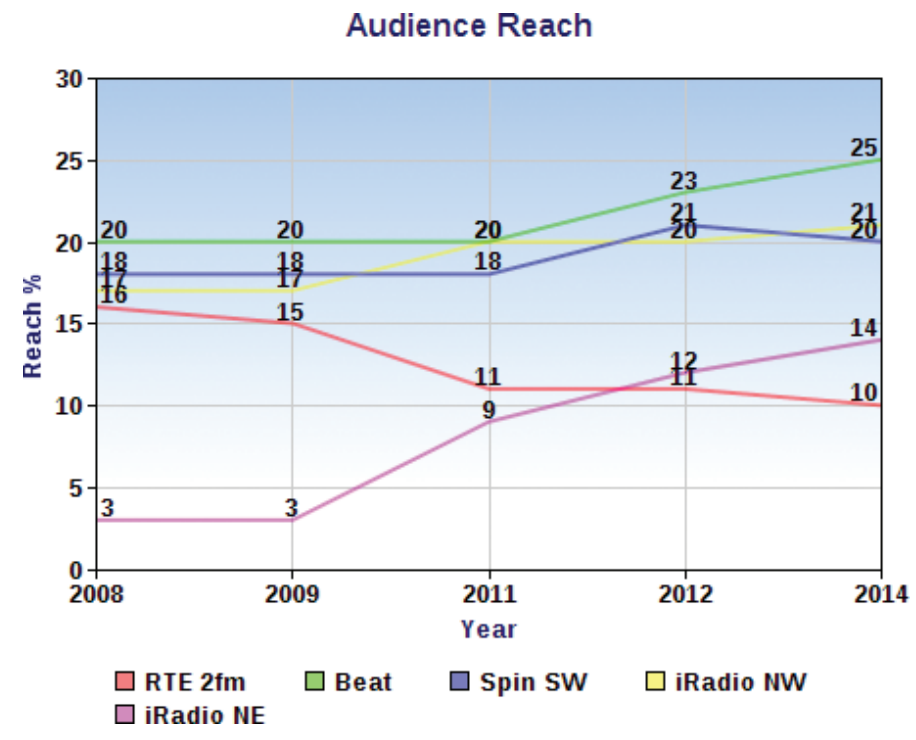

Figure 1. Youth Radio Station Audience Reach 2008-2014.

\section{Facing the Facts: A Shift in Listenership}

Since its launch in 1979 Radio 2/ 2fm / RTÉ 2fm has generally enjoyed a strong national reach and market share, second only to RTÉ Radio 1. However, from 2008 that position was challenged and its listenership eroded. The drop in ratings had been partly attributed to the untimely death of the popular mid-morning talk show presenter, Gerry Ryan, in May 2010. This author argues that a more prominent factor was the station's reluctance to embrace the power of digital media including social media platforms to further engage the audience and attract new listeners. This was a strategic oversight. The regional youth radio stations outside of Dublin, of which there were four; Beat, Spin South West, iRadio NE and iRadio NE, all grew their reach to young listeners steadily from 2008 to 2014 while RTÉ 2fm's audience dropped (see Figure 1). ${ }^{34}$

In the period from January 2008 to July 2014, a six-and-a-half-year period, RTÉ $2 \mathrm{fm}$ suffered a loss in its national weekday reach from $16 \%$ to $10 \%$ - a decline of six percentage points ${ }^{35}$. The station therefore lost roughly one third of its share of listeners in that period and due to audience figures being innately tied to advertising revenue it is no surprise that 2fm's revenue had dropped significantly in this time also. During the same time period 2008-2014, there were gains made by regional youth-oriented radio stations. Beat had an increase of five percentage points in five years; Spin South West increased its reach from 18\% to $20 \%$ (+2\%); iRadio NW increased from $17 \%$ to $21 \%(+4 \%)$; and iRadio NE climbed the most, jumping from $3 \%$ to $14 \%(+11 \%){ }^{36}$

In terms of market share, a measure of the segment of airtime between $7 \mathrm{am}$ and $7 \mathrm{pm}$ for which a station holds audiences, the figures reflect a similar trend. RTÉ 2 fm's market share went from $10.1 \%$ in 2009 to $6.6 \%$ in mid 2014 , a drop of 3.5 percentage points, or one third. Over the same time period Beat increased its share from $12.2 \%$ to $16.7 \%(+4.5 \%)$, Spin South West increased from $9.8 \%$ to $10.4 \%(+0.6 \%)$, iRadio NW from $11 \%$ to $12.3 \%(+1.3 \%)$ and iRadio NE jumped from $2.0 \%$ to $9.0 \%(+7.0 \%) .{ }^{37}$ 
The drop in RTÉ $2 \mathrm{fm}$ listeners and the coincidental rise in listeners of competing youth stations evidences that young audiences were initially attracted to, or switched allegiance to, the regional youth stations. Furthermore, this author argues, young radio audiences that were new to radio and replenished the listener stock were attracted to the regional youth stations, over RTÉ $2 \mathrm{fm}$. These new listeners learned of their regional youth station before they learned of RTÉ because regional stations were more prominent online and proved to be dynamic and exciting in their use of social media to reach that market segment. Young people were attracted to commercial stations by viral content such as memes, videos and GIFs disseminated via social media. Textual analysis offered evidence that posts that used the power of nostalgia and tapped into the audience's shared sense of community were very effective at engaging existing audience and expanding the station's reach to new users. One exemplary post from May 2015 featured an image of the Teletubbies dolls and carried the caption "Remember the Teletubbies shortage of 1997". This post received a substantial qualitative and qualitative response from users as people shared their memories with others in their social network and reminisced about their childhood. The post had the effect of coalescing a cohort that had fond memories of that dramatic event from their youth. The post garnered 3,035 emoji reactions, 239 shares and 210 comments in the days immediately after its publication on Facebook. Such posts contributed to increases in followers to the Beat Facebook page, followers who are likely to then become Beat listeners.

\section{Why are Listeners Tuning Out?}

The reasons for the shift in listeners can be attributed to a number of factors that the author argues put RTÉ 2fm out of touch with its target audience. One of the crucial issues stemmed from the fact that the staff, presenters in particular, were born into a different generation and thus were out of touch with the target audience. The youngest primetime presenter at the time of research was 42 - though RTÉ has moved to address this issue since. As a result of the older presenters the tastes, habits, experiences, priorities and perspectives on life of the millennial generation were likely not properly understood or appreciated. These millennial habits include large amounts of time spent on, and communicating through, social media and visual engagement through multiple screens.

Interestingly, the RTÉ $2 \mathrm{fm}$ staff interviewed in 2013 did not see audience retention or recruitment as a primary motivating factor for using Facebook. The two media were seen as mutually exclusive. This reflects the attitude RTÉ $2 \mathrm{fm}$ had at the time towards social and media digitalisation in general which, this author argues, had a negative effect on the station's listenership. Add to this RTÉ's aforementioned conservative nature, its relatively large size and thus inherent inability to enact swift change and the picture becomes more clear. ${ }^{38}$ In such a large and complex organisation, culture and policy change can be hard to instigate, let alone implement. Conversely an independent radio station with a small and intimate team can be highly responsive to change and opportunity and consequently implement alternatives relatively swiftly. Despite RTÉ 2fm's woes all was not lost. Given RTÉ's enviable financial resources and admittedly brave, yet lethargic leadership, a brighter future was attainable and would eventually arrive.

\section{Game Changer: RTÉ Rings the Changes}

To the organisation's credit RTÉ ultimately accepted that change was needed. In early 2015, less than two years after the primary research for this paper was conducted, the organisation published Digital Priorities 2015-16 in which the state broadcaster announced plans to make sweeping changes. The remit of the new policy was clear - "to extend public value in the digital age". ${ }^{39}$ RTÉ outlined what was planned to achieve in response to a changing mediascape in which digital communication technology had advanced greatly, and audience behaviour and expectations had also transformed. In the opening pages it pledged to "change to stay ahead" and the plan would allow the organisation to deliver on "the next stage of the digital transformation" by meeting the current and future needs of their audience 
based on their new patterns of consumption. ${ }^{40}$ RTÉ also hoped to develop innovative ways of developing existing products and create new ones to best serve the audience. Inclusivity of all demographics of the Irish audience was also key to this strategy, and their remit as a PSB, as was the development of new online revenue streams. The latter was clearly in response to the move to digital online advertising - an area of future growth in advertising spend. The document set out priorities and digital goals to be achieved over a two-year period. The strategy applied to all of RTÉ's outputs - radio, television and online. This was to be a comprehensive change across all platforms but the most noticeable changes were made to RTÉ $2 \mathrm{fm}$ which was almost unrecognisable after a complete transformation.

In a message to the staff the document stated, "As the market continues to change, we will need everyone to embrace the opportunities these new digital tools give us to tell stories and to connect with, inform and entertain our audiences". ${ }^{41}$ The digital strategy document is profound in many ways as it identified the need for change within RTÉ to keep up with the competition, for this change to happen immediately, and for the organisation as a whole to become a more integrated, synergised, and digital RTÉ.

In the modern, dynamic media environment, RTÉ correctly identified the need to deliver media on the audience's terms, because as discussed earlier, the audience now has more power, influence and media options than ever before. RTÉ noted the need to arrest the slide in audience figures at RTÉ 2fm and stated that "as RTÉ's leading service for younger audiences, during 2015/2016 2fm will radically update its digital presence and activity". RTÉ identified priorities which included re-developing the website, their digital media players, and specifically improving RTÉ 2fm's online and mobile presence. ${ }^{42}$

One of the most noticeable changes implemented was the installation of fixed, multi-camera infrastructure in the RTÉ $2 \mathrm{fm}$ studios which addressed one of the needs identified in the document - to make radio and in-studio musical performances more visual ${ }^{43}$. Using this new technology, along with a rebranding of the RTÉ $2 \mathrm{fm}$ logo, and a complete refit of the radio studio interiors for the viewing audience, every radio programme is now streamed live on Facebook Live so audiences can watch and listen to the radio show online. Furthermore, production staff post segments of RTÉ $2 \mathrm{fm}$ programmes on Facebook for listeners and viewers to catch-up with later in the day. Beat were also streaming some live video content from their studios and on location by this time but not to the same consistent level as RTÉ $2 \mathrm{fm}$. This has much to do with the financial cost associated with installing several cameras and refitting studio interiors.

RTÉ also realised the need for personnel changes as part of the rejuvenation to invigorate the programming and image. This involved redistributing the old guard, many of whom had been with RTÉ $2 \mathrm{fm}$ for decades, some since its inception, and replacing them with younger, more dynamic, and social media savvy presenters. This was a bold move for RTÉ, representing a deep cultural transformation. The median presenter age dropped substantially and fresh new faces, including former Westlife heartthrob Nicky Byrne and presenters Louise McSharry and Eoghan McDermott were now the new faces of RTÉ $2 \mathrm{fm}$ - faces that would generate more visibility given the increased visualisation offered through Facebook Live. The changes appear to have worked as RTÉ $2 \mathrm{fm}$ stopped haemorrhaging listeners and was able to show some limited listenership growth. At the time of writing in early 2019, the RTÉ $2 \mathrm{fm}$ Facebook page had shown significant growth in Facebook followers, boasting over 540k. This is evidence that RTÉ has managed to improve its standing and popularity among its audiences online and on-air and looks to have positioned itself well for the future. And these changes have continued. In May 2019 a further presenter shake-up saw more female presenters given primetime programme slots, clearly in response to calls for better gender balance on RTÉ $2 \mathrm{fm}$ and Irish radio generally.

\section{Conclusion}

The substantial changes implemented by RTÉ outlined above serve as evidence of the station's shift to be bolder and more innovative in terms of infrastructure, equipment and staff. There remains the question of whether the online output, which is crucial to attracting and maintaining young audiences, has been improved. There is now a heavy focus on live 
and playback of in-studio video and while this is proving popular as it gives radio a visual element it is not exactly novel and could become repetitive before long. RTÉ will have to continue to develop and adapt to match the wants and needs of the ever changing, increasingly demanding audience.

This article argues that the commercial radio sector in Ireland in a sense rescued the Irish Radio Industry and helped radio maintain its relevance, particularly among the young millennial audience. Millennial audiences are much more digitally and visually immersed than previous audiences and thus expect a far wider media offering from radio stations. Commercial radio led the required change through innovative leadership which was forced mainly by economic and technological factors, to change how radio is produced and delivered. Commercial radio also helped alter how the audience should be perceived - as valued and invested participants.

It appears evident that in witnessing the success of its Irish competitors, as well as other radio stations in Ireland and Europe, that RTÉ eventually made the decision to embrace change and adopt new digital opportunities. Other influences outside of Ireland would have been the BBC, and in particular the leading youth oriented radio station BBC Radio 1 along with the prominent commercial radio brands Kiss and Capital all of which have had highly dynamic SNS use and have had in-studio cameras for a number of years. The leadership and innovation shown by the commercial sector represents the possible shift in perception that PSBs are the industry leaders and the standard bearers for production quality and professionalism for the other sectors to follow. Certainly commercial stations were quicker to adapt to the shift in power towards the audience member and create an offering that suited their tastes and desire for increased agency.

SNS platforms have allowed radio audience participation to expand rapidly and have extended the reach of radio stations beyond audio broadcasts. Despite the nearly instant adoption of social media platforms, particularly Facebook, by all public service and commercial radio stations in Ireland from 2008, public service stations were not as effective as their independent commercial counterparts in exploiting the benefits these services offered. This case study of the Irish Radio Industry showed how the independent commercial sector was much more responsive, dynamic, innovative and digitally connected than the state broadcaster RTÉ. The contrasting fortunes in terms of listenership can be attributed, at least in part, to the limited SNS presence and overall digital innovation shown by the PSB and the general oversight of the need for radio to adapt to the digital age. This stands as a contemporary example of how commercial radio has led the way and shown innovation, dynamism and creativity for RTÉ to learn from.

Based on the findings of this research the author argues that RTÉ $2 \mathrm{fm}$ ought to reconsider its position within the Irish media market and what audience it wants to serve. The discrepancy between the commercial youth stations target audience of 15-34 and RTÉ 2fm's target of 20-44 means that RTÉ is at a disadvantage when it comes to attracting listeners before the competition does. The interviews found that commercial stations use SNSs to attract young audiences even younger than 15 - as early as 13, offering these stations a further competitive edge.

RTÉ benefited greatly by initially learning from, and subsequently following, the leadership shown by the commercial radio sector. Once mobilised, RTÉ was able to adopt the required strategies and digital production practices, upgrade studios and technology, rebrand their image, visualise their output, and recruit or redeploy human resources into new roles to suit the new direction. After these changes were enacted the public service broadcaster was in a much better position and is currently poised to take on the current digital age in which the key battleground has become the fight to secure the attention of the next generations of radio listeners.

Independent commercial broadcasters are typically smaller organisations with limited financial support, and thus more vulnerable to economic hardship. However, this fosters flexibility, responsiveness and vitality, and an ability to adapt in a fast-moving, modern digital mediascape. PSBs in contrast tend to be large, cumbersome and conservative and thus less responsive to change. However, given time to plan and implement development, the superior finances and supporting resources PSBs enjoy can allow them to accelerate and move ahead of the competition and thus consolidate their position as industry leaders. 
At a time when independent Irish radio stations are struggling financially because of shifting advertising revenues, the findings of this research are valuable. The research illustrates how commercial radio helped the Irish Radio Industry modernise and thus maintain relevance with not only today's, but tomorrow's young media users. The research also promotes the case for the protection of the public service, commercial and community radio sectors as part of a healthy radio industry which upholds the public service mission.

Radio, being the resilient medium that it is, has had to change to find its place and secure its future in an increasingly competitive environment. Change is a fundamental part of radio's make-up. The medium has had to attract the next generation of listeners for whom radio is not their first medium. What radio has not done, and must not do, is change itself to the extent that it loses its distinctiveness as a unique and primarily aural medium which supplies Irish people with the news, entertainment and information habitually, and acts as their constant daily companion.

\section{Notes}

1. Marc Prensky, 'Digital Natives, Digital Immigrants,' On the Horizon, 9, 5, 2001, 1-6.

2. John Palfrey and Urs Gasser, 'Born Digital: Understanding the First Generation of Digital Natives,' in David Haugen and Susan Musser, eds, The Millennial Generation, Greenhaven Press, 2008.

3. Christian Fuchs, Social Media: A Critical Introduction, Sage, 2014.

4. I Ipsos MRBI, Joint National Listenership Research Q3 Summary Results, Ipsos MRBI, 2018.

5. Ipsos MRBI, Joint National Listenership Research Q3 Summary Results, Ipsos MRBI, 2011.

6. Ipsos MRBI, Joint National Listenership Research, 2018.

7. Ibid.

8. Reuters Institute, 'Reuters Institute Digital News Report,' 2018. See also http://www.ibireland.ie/radio-takes-top-spot-in-thereuters-news-report/

9. Peter Mulryan, Radio, Radio: The Story of Independent, Local, Community and Pirate Radio in Ireland, Borderline Publications, 1988.

10. Gregory Ferrell Lowe and Päivi Maijanen, 'Making Sense of the Public Service Mission in Media: Youth Audiences, Competition and Strategic Management,' Journal of Media Business Studies, 16, 1, 2019, 1-18.

11. Henry Jenkins, Convergence Culture: Where Old and New Media Collide, New York University Press, 2006.

12. Alvin Toffler, Future Shock, Pan Books, 1971.

13. Alex Bruns, 'Towards Produsage: Futures for User-Led Content Production,' in Fay Sudweeks, Herbert Hrachovec, and Charles Ess, eds, Cultural Attitudes towards Technology and Communication. Proceedings of the Fifth International Conference on Cultural Attitudes towards Technology and Communication, Murdoch University, 2006.

14. Jay Rosen, 'The People Formerly Known as the Audience,' PressThink, 27 June 2006, http://archive.pressthink. org/2006/06/27/ppl_frmr.html

15. Jo Bardoel and Gregory Ferrell Lowe, 'From Public Service Broadcasting to Public Service Media: The Core Challenge,' in Gregory Ferrell Lowe and Jo Bardoel, eds, From Public Service Broadcasting to Public Service Media RIPE@2007, Nordicom, 2007, pp. 9-26.

16. Jenkins, Convergence Culture, 2006.

17. Fuchs, Social Media, 2014.

18. Neil Howe and William Strauss, Millennials Rising: The Next Great Generation, Vintage Books, 2000.

19. Prensky, 'Digital Natives, Digital Immigrants,' 2001.

20. James McDonnell, Public Service Broadcasting: A Reader, Routledge, 1991; Paddy Scannell, 'Public Service Broadcasting: The History of a Concept,' in Andrew Goodwin and Garry Whannel, eds, Understanding Television, Routledge, 1990, pp. 11-26.

21. David Hendy, Public Service Broadcasting, Red Globe Press, 2013

22. Ofcom, 'Public Service Broadcasting in the Internet Age: Ofcom's Third Review of Public Service Broadcasting,' Office of Communications, 2015.

23. Raidió Teilifís Éireann, Change and Challenge: The Future for Broadcasting in Ireland, RTÉ, 1989; Richard Pine, 2RN and the Origins of Irish Radio, Four Courts Press, 2002; John Horgan, Broadcasting and Public Life: RTÉ News and Current Affairs, 1926-1997, Four Courts Press, 2004; Harry Browne, 'Wiles of the Wireless: Radio and Critical Discourse in Ireland,' The Irish Review, 32, Autumn-Winter 2004, 69-76.

24. Peter Mulryan, Radio, Radio: The Story of Independent, Local, Community and Pirate Radio in Ireland, Borderline Publications, 1988. 
25. Lowe and Maijanen, 'Making Sense of the Public Service Mission in Media,' 2019.

26. Pentti Kemppainen, 'The Channel Reform of Public Service Radio in the Nordic Countries,' Journal of Radio Studies, 5, 1, 1998, 132-149.

27. British Broadcasting Corporation, 'Extending Choice: The BBC's Role in the New Broadcasting Age,' British Broadcasting Corporation, 1992.

28. Chava Frankfort-Nachmias and David Nachmias, Research Methods in the Social Sciences, Worth Publishers, 2000.

29. Gunn Sara Enli and Karoline A. Ihlebaek, 'Dancing with the Audience: Administrating Vote-Ins in Public and Commercial Broadcasting,' Media, Culture \& Society, 33, 6, 2011, 953-962.

30. Karl Mannheim, 'The Problem of Generations,' in Paul Kecskemeti, ed, Essays on the Sociology of Knowledge: Collected Works, Volume 5, Routledge, 1952, pp. 276-322.

31. Browne, 'Wiles of the Wireless,' 2004, 73.

32. Lowe and Maijanen, 'Making Sense of the Public Service Mission in Media,' 2019.

33. Mulryan, Radio, Radio, 1988.

34. Ipsos MRBI, Joint National Listenership Research Annual Summary Results, Ipsos MRBI, 2008; Ipsos MRBI, Joint National Listenership Research Annual Summary Results, Ipsos MRBI, 2014.

35. Ibid.

36. Ibid.

37. Ipsos MRBI, Joint National Listenership Research Annual Summary Results, Ipsos MRBI, 2009; Ipsos MRBI Joint National Listenership Research, 2014

38. Browne, 'Wiles of the Wireless,' 2004, 73.

39. Raidió Teilifís Éireann, Digital Priorities 2015-16, RTÉ, 2014, p. 1.

40. Ibid., p. 4

41. Ibid.

42. Ibid., p. 9

43. Ibid.

\section{Bi o graphy}

Dr Daithí McMahon, PhD is a Programme Leader and Senior Lecturer at the University of Derby where he lectures in radio/audio production and scriptwriting at undergraduate and postgraduate levels. His current research interests include the convergence of radio and social media, digital media and diaspora communities, and digital media and youth audiences. Daithí is also a critically acclaimed and multi-award-winning writer, director, and radio producer and leads collaborative, multidisciplinary projects including ambisonic audio drama, true crime podcasts, and oral history projects involving School of Arts students. 